\title{
Gas biology: small molecular medicine
}

\author{
Gregg L. Semenza • Nanduri R. Prabhakar
}

Published online: 17 February 2012

(C) Springer-Verlag 2012

In this special issue of the Journal of Molecular Medicine, we present five review articles concerning small molecules that play big roles in physiology and medicine: the gases oxygen $\left(\mathrm{O}_{2}\right)$, nitric oxide $(\mathrm{NO})$, carbon monoxide $(\mathrm{CO})$, and hydrogen sulfide $\left(\mathrm{H}_{2} \mathrm{~S}\right)$. Of these, the essential requirement for $\mathrm{O}_{2}$ is well known to physicians, scientists, and laymen alike. However, it is only within the last two decades that we have begun to understand the molecular mechanisms by which every cell in our body senses the local $\mathrm{O}_{2}$ concentration and responds to reduced $\mathrm{O}_{2}$ availability (i.e., hypoxia) with changes in gene expression that are mediated by the hypoxia-inducible factors HIF-1 and HIF-2 [1]. Recent evidence suggest that $\mathrm{NO}, \mathrm{CO}$, and $\mathrm{H}_{2} \mathrm{~S}$ function as signaling molecules that also play critical roles in regulating $\mathrm{O}_{2}$ homeostasis.

Philip Marsden and colleagues (University of Toronto) describe the fascinating crosstalk between $\mathrm{O}_{2}$ sensing and NO signaling that occurs to regulate red blood cell levels

\section{G. L. Semenza $(\bowtie)$}

Vascular Program, Institute for Cell Engineering;

Departments of Pediatrics, Medicine, Oncology,

Radiation Oncology, and Biological Chemistry,

The Johns Hopkins University School of Medicine,

Baltimore, MD, USA

e-mail: gsemenza@jhmi.edu

\section{G. L. Semenza}

McKusick-Nathans Institute of Genetic Medicine, The Johns Hopkins University School of Medicine, Baltimore, MD, USA

\section{N. R. Prabhakar}

Institute for Integrative Physiology and Center for Systems

Biology of O2 Sensing, The University of Chicago,

Chicago, IL, USA

e-mail: nanduri@uchicago.edu and blood vessel tone, which together play critical roles in $\mathrm{O}_{2}$ delivery [2]. In particular, they discuss exciting data from their lab demonstrating that the physiological responses to anemic hypoxia (reduced $\mathrm{O}_{2}$ carrying capacity) and hypoxic hypoxia (reduced $\mathrm{O}_{2}$ ) are mechanistically distinct. This difference is dramatically illustrated by their finding that subjecting mice that lack neuronal NO synthase (also known as nNOS or NOS1) to anemic hypoxia resulted in an increased mortality rate, compared to wild-type mice, whereas these NOS1-deficient mice were protected against mortality during hypoxic hypoxia [3]. Their delineation of the molecular and cellular basis for these effects is truly elegant physiology. The crosstalk between $\mathrm{O}_{2}$ sensing and NO signaling is extensive and includes increased expression of inducible NOS (also known as iNOS or NOS2) under hypoxic conditions that is mediated by HIF-1 [4, 5] and the regulation of HIF-1 activity by S-nitrosylation of a cysteine residue in the HIF-1 $\alpha$ subunit [6].

Puneet Anand and Jonathan Stamler (Case Western Reserve University) provide a global view of protein Snitrosylation and its effects on protein function [7]. They describe several different molecular mechanisms by which proteins are nitrosylated and counteracting mechanisms by which they are denitrosylated, which is analogous to the phosphorylation and dephosphorylation of proteins by kinases and phosphatases. The balance between nitrosylation and denitrosylation is dependent on the redox state of the cell, thus establishing inherent crosstalk between $\mathrm{NO}$ and reactive oxygen species. The authors discuss several examples of diseases associated with dysregulated S-nitrosylation, which may therefore represent a novel therapeutic target.

Makoto Suetmatsu and colleagues (Keio University) discuss the biological role of $\mathrm{CO}$, which is generated by heme oxygenases ( $\mathrm{HO} 1$ and $\mathrm{HO} 2$ ) using heme and $\mathrm{O}_{2}$ as 
substrates [8]. They discovered that CO binds to the heme moiety of cystathionine $\beta$-synthase (CBS), an enzyme that generates $\mathrm{H}_{2} \mathrm{~S}$, and that $\mathrm{CO}$ inhibits $\mathrm{CBS}$ catalytic activity [9]. More recently, an elegant series of experiments have revealed that in the brain, $\mathrm{CO}$ is generated by $\mathrm{HO}$, binds to CBS, and inhibits its activity; however, under hypoxic conditions, $\mathrm{CO}$ production falls, $\mathrm{CBS}$ is no longer inhibited, resulting in the production of $\mathrm{H}_{2} \mathrm{~S}$, which functions as a vasodilator [10]. Thus, changes in $\mathrm{O}_{2}$ availability result in adaptive changes in cerebral vascular tone (and tissue perfusion) at least in part through changes in $\mathrm{HO} 2-$ and CBS-dependent production of $\mathrm{CO}$ and $\mathrm{H}_{2} \mathrm{~S}$, respectively.

Scott Vandiver and Solomon Snyder (Johns Hopkins University) focus on the mechanisms and consequences of $\mathrm{H}_{2} \mathrm{~S}$ production [11]. In addition to $\mathrm{CBS}, \mathrm{H}_{2} \mathrm{~S}$ is also generated by cystathionine $\gamma$-lyase (CSE) and 3-mercaptopyruvate sulfotransferase. $\mathrm{H}_{2} \mathrm{~S}$ mediates biological effects by sulfhydration of thiol groups of cysteine residues within proteins, including the glycolytic enzyme glyceraldehyde-3-phosphate dehydrogenase, leading to increased enzyme activity [12]. Sulfhydration of ATP-dependent potassium channels mediates the vasodilation described above [13]. Just as Anand and Stamler review the evidence that protein nitrosylation mediates the effects of NO, Vandiver and Snyder show that sulfhydration is emerging as a novel and widespread posttranslational modification that mediates the effects of $\mathrm{H}_{2} \mathrm{~S}$.

In the final paper, we describe how $\mathrm{NO}, \mathrm{CO}$, and $\mathrm{H}_{2} \mathrm{~S}$ are all involved in $\mathrm{O}_{2}$ sensing and signal transduction by the carotid body, a small sensory organ located at the bifurcation of the common carotid artery [14]. Glomus cells within the carotid body sense the arterial $\mathrm{O}_{2}$ concentration and transduce neural signals to the brain centers that control respiration and blood pressure in order to increase tissue oxygenation. Remarkably, carotid bodies from mice that are heterozygous for a knockout allele at the locus encoding HIF- $1 \alpha$ do not respond to hypoxia [15], whereas carotid bodies from mice that are heterozygous for a knockout allele at the locus encoding HIF- $2 \alpha$ show exaggerated responses to hypoxia [16], providing evidence that the homeostatic responses mediated by the carotid body are dependent upon a balance between HIF-1 and HIF-2. Glomus cells express CSE and carotid bodies from mice lacking CSE also do not respond to hypoxia [17], whereas NOS1-deficient mice exhibit exaggerated ventilatory responses to hypoxia [18]. Treatment with a $\mathrm{CO}$ donor blocks hypoxia-induced $\mathrm{H}_{2} \mathrm{~S}$ production, suggesting that $\mathrm{CO}$ produced by $\mathrm{HO} 2$ inhibits CSE activity in the carotid body [17], although the mechanism of action is unknown because, unlike CBS, CSE does not contain a heme group to which $\mathrm{CO}$ can bind. The targets of sulfhydration by $\mathrm{H}_{2} \mathrm{~S}$ in the carotid body also remain to be determined.
Taken together, these review articles demonstrate that $\mathrm{O}_{2}$, $\mathrm{NO}, \mathrm{CO}$, and $\mathrm{H}_{2} \mathrm{~S}$ play critical roles in a wide range of fundamental homeostatic mechanisms, which become dysregulated in various disease processes. It is likely that future studies will uncover many more clinical contexts in which the action of these small molecules is relevant and may be targeted therapeutically.

\section{References}

1. Semenza GL (2011) Oxygen sensing, homeostasis, and disease. N Engl J Med 365:537-547

2. Ho JJD, Man HSJ, Marsden PA (2012) Nitric oxide signaling in hypoxia. J Mol Med. doi:10.1007/s00109-012-0880-5 (this issue)

3. Tsui AK, Marsden PA, Mazer CD, Adamson SL, Henkelman RM, Ho JJ, Wilson DF, Heximer SP, Connelly KA, Bolz SS et al (2011) Priming of hypoxia-inducible factor by neuronal nitric oxide synthase is essential for adaptive responses to severe anemia. Proc Natl Acad Sci USA 108:17544-17549

4. Melillo G, Taylor LS, Brooks A, Cox GW, Varesio L (1996) Regulation of inducible nitric oxide synthase expression in IFN- $\gamma$-treated murine macrophages cultured under hypoxic conditions. J Immunol 157:2638-2634

5. Palmer LA, Semenza GL, Stoler MH, Johns RA (1998) Hypoxia induces type II NOS gene expression in pulmonary artery endothelial cells via HIF-1. Am J Physiol 274:L212-L219

6. Li F, Sonveaux P, Rabbani ZN, Liu S, Yan B, Huang Q, Vujaskovic Z, Dewhirst MW, Li CY (2007) Regulation of HIF-1 $\alpha$ stability through S-nitrosylation. Mol Cell 26:63-74

7. Anand P, Stamler JS (2012) Enzymatic mechanisms regulating protein S-nitrosylation: implications in health and disease. J Mol Med. doi:10.1007/s00109-012-0878-z (this issue)

8. Hishiki T, Yamamoto T, Morikawa T, Kubo A, Kajimura M, Suetmatsu M (2012) Carbon monoxide: impact on remethylation/ transsulfuration metabolism and its pathophysiologic implications. J Mol Med. doi:10.1007/s00109-012-0875-2 (this issue)

9. Shintani T, Iwabuchi T, Soga T, Kato Y, Yamamoto T, Takano N, Hishiki T, Ueno Y, Ikeda S, Sakuragawa T et al (2009) Cystathionine $\beta$-synthase as a carbon monoxide-sensitive regulator of bile excretion. Hepatology 49:141-150

10. Morikawa T, Kajimura M, Nakamura T, Hishiki T, Nakanishi T, Yukutake Y, Nagahata Y, Ishikawa M, Hattori K, Takenouchi T et al (2012) Hypoxic regulation of the cerebral microcirculation is mediated by a carbon monoxide-sensitive hydrogen sulfide pathway. Proc Natl Acad Sci USA 109(4):1293-1298

11. Vandiver MS, Snyder SH (2012) Hydrogen sulfide: a gasotransmitter of clinical relevance. J Mol Med. doi:10.1007/s00109-0120873-4 (this issue)

12. Mustafa AK, Gadalla MM, Sen N, Kim S, Mu W, Gazi SK, Barrow RK, Yang G, Wang R, Snyder SH (2009) $\mathrm{H}_{2} \mathrm{~S}$ signals through protein S-sulfhydration. Sci Signal 2(96):ra72

13. Mustafa AK, Sikka G, Gazi SK, Steppan J, Jung SM, Bhunia AK, Barodka VM, Gazi FK, Barrow RK, Wang R et al (2011) Hydrogen sulfide as endothelium-derived hyperpolarizing factor sulfhydrates potassium channels. Circ Res 109:1259-1268

14. Prabhakar NR, Semenza GL (2012) Gaseous messengers in oxygen sensing. J Mol Med. doi:10.1007/s00109-012-0876-1 (this issue)

15. Kline DD, Peng YJ, Manalo DJ, Semenza GL, Prabhakar NR (2002) Defective carotid body function and impaired ventilatory responses to chronic hypoxia in mice partially deficient 
for hypoxia-inducible factor $1 \alpha$. Proc Natl Acad Sci USA 99:821-826

16. Peng YJ, Nanduri J, Khan SA, Yuan G, Wang N, Kinsman B, Vaddi DR, Kumar GK, Garcia JA, Semenza GL et al (2011) Hypoxiainducible factor $2 \alpha$ (HIF-2 $\alpha$ ) heterozygous-null mice exhibit exaggerated carotid body sensitivity to hypoxia, breathing instability, and hypertension. Proc Natl Acad Sci USA 108:3065-3070
17. Peng YJ, Nanduri J, Raghuraman G, Souvannakitti D, Gadalla MM, Kumar GK, Snyder SH, Prabhakar NR (2010) $\mathrm{H}_{2} \mathrm{~S}$ mediates $\mathrm{O}_{2}$ sensing in the carotid body. Proc Natl Acad Sci USA 107:10719-10724

18. Kline DD, Yang T, Huang PL, Prabhakar NR (1998) Altered respiratory responses to hypoxia in mutant mice deficient in neuronal nitric oxide synthase. J Physiol 511:273-287 